\title{
Struktur Komunitas Lana Ikan Pada Ekosistem Padang Lamun Di Perairan Jepara
}

\author{
Ita Riniatsih \\ Departemen Ilmu Kelautan, Fakultas Perika nan dan Ilmu Kelautan, Universitas Diponegoro \\ JI. Prof. Soedarto, SH. Kampus UNDIP Tembalang, Semarang 50275 \\ Email: Irinia tsih@yahoo.com
}

\begin{abstract}
Abstrak
Ekosistem padang lamun sebagai salah satu ekosistem di wilayah pesisir yang produktif mempuya i fungsi sec ara ekologis sebagai tempat untuk memijah, daerah asuhan bagi larva yang dihasilkan dan tempat untuk mencari makan berbagai organism laut yang hidup di dalamnya. Kelestarian dan keanekaragaman organism laut sangat tergantung dari keberadaan dan kondisi biofisik padang lamun sebagai habitat sementara atau habitat selama siklus hidupnya. Penelitian tentang kajian fungsi ekologis padang lamun ini dilakukan untuk melihat seberapa jauh keterkaitan tentang kondisi padang lamun dengan keaneragaman larva ikan yang memanfaatkan padang lamun untuk tempat berlindung dan mencari makan. Penelitian dengan metoda deskriptif ini dilakukan di ekosistem pa dang la mun J epara di perairan Teluk Awur, Pantai Bandengan dan perairan Mororejo. Sampel ikan di tangkap dengan menggunakan jaming sudu, yang didorong sepanjang 150 meter sejajar garis pantai. Jumlah total larva ikan yang tertangkap selama penelitian adalah sebanyak 570 ekor dari 12 famili. Hasil identifikasi mempenlihatkan famili ikan yang tertangkap adalah Apogonidae, Carapidae, Blenniidae, Egraulidae, Epilephenidae, Gemidae, Heniranphidae, Labridae, Gobiidae, Lutjanidae, Syngnathidae, Mullidae, dan Siganidae. Famili ikan yang teridentifikasi didominasi dari famili Gobiidae, Bleniidae dan Eugraulidae. Berdasarkan lokasi pengamatan, lokasi perairan Bandengan merupakan lokasi dengan hasil tangkapan larva ikan tertinggi, yaitu sebanyak 9 famili, perairan Teluk Awur sebanyak 7 famili dan perairan Mororejo sebanyak 5 famili.
\end{abstract}

Kata kunci: larva ikan, padang lamun, perairan J epara

\section{PENDAHULUAN}

Padang lamun sebagai salah satu ekosistem di wilayah pesisir seca ra ekolog is mempunyai fungsi sebagai daerah asuhan bagi organisme muda dan memegang peranan penting dalam menjaga kelestarian dan keanekaragaman orgnisme laut. Allen et al., (1980) dalam Riniatsih et al., (2007) menjelaskan bahwa keanekaragaman perikanan pantai tergantung pada biotabiota muda yang hidup diantara area pasang surut, tempat mereka berlindung dan memperoleh cukup makanan pada masa-masa awal hidupnya.

Ekosistem padang lamun selama ini dianggap kurang mempunyai nilai ekonomi penting, sebenamya dapat memberi sumbangan yang sangat besar untuk menjaga kelestarian berbagai jenis organism laut (Tomascick et al., 1997 dan Suyanto, 1979 dalam Riniatsih et al., 2007 ). Berdasarkan keterangan diatas dapat diketahui betapa pentingnya peranan padang lamun sebagai daerah pemijahan, asuhan dan daerah mencari makan berbagai jenis organisme laut sebenamya dapat penopang kelimpahan dan struktur komunitas larva ikan, bivalvia, gastropoda, krustasea dan organism laut lainnya yang berasosiasi didalamnya. Sehubungan dengan masih kurangnya informasi mengenai kajian fungsi ekologis padang lamun dengan melihat struktur komunitas la rva orga nisme laut yang berasosiasi di padang lamun khususnya di perairan Jepara (perairan padang lamun di Teluk Awur, Bandengan 
dan perairan Mororejo Demeling), maka penelitian ini perlu dilakukan.

Ekosisistem padang lamun merupakan salah satu ekosistem utama di wilayah pesisir yang mempunyai peranan penting dalam menjaga keseimbangan ekosistem di perairan laut. Salah satu fungsi fisik padang lamun adalah sebagai peredam gelombang alami di wilayah pesisir, sehingga dapat menciptakan lingkungan laut yang tenang dan teduh yang sangat disukai oleh berbagai jenis organisme laut, khususnya ikan. Ikan laut banyak memanfaatkan ekosistem padang lamun sebagai tempat mencari makan, tempat berlindung dari predator ataupun tempat untuk pembesaran (Danovaro et al., 2002).

Daur hidup sebagian besar organisme laut dimulai dari fase peneluran, salah satunya di wilayah padang lamun, kemudian stadia larva yang menghuni daerah asuhan di ekosistem padang lamun dan hidup di habitat tersebut hingga stadia juvenile untuk kemudian bemigrasi kembali ke la ut hingga tumbuh dewasa dan kemudian kembali untuk memijah kembali (Romimuhtarto dan Juwana, 2001; Rinia tsih et al., 2000).

Karakteristik habitat padang lamun sangat berpengaruh pada kelimpahan dan distribusi larva dan organisme laut lainnya yang berasosiasi di dalamnya. Hal ini dikarenakan adanya pengaruh kondisi fisika, kimia dan biologi perairan yang sangat mempengaruhi kondisi padang lamun. Parameter-parameter tersebut antara la in adalah: suhu, kecepatan arus, kecerahan, salinitas, fraksi substrat dasar, keberadaan fitoplankton dan zooplankton serta hewan bentik lainnya. Selain itu kerapatan jenis lamun sangat tergantung dari fraksi substrat serta kondisi kimia zat hara substrat dasartempat lamun tumbuh (Tomascik et al., 1997; Riniatsih et al., 2001).

Penelitian ini bertujuan untuk mengkaji karakteristik biofisik perairan padang lamun perairan J epara dan untuk mendapatkan gambaran tentang struktur komunitas dan distribusi berbagai jenis larva dan organisme laut di padang lamun perairan J epara.

Setiap jenis ikan mempunyai atau memiliki habitat yang berbeda-beda, ada yang dari larva hingga dewasa hidup di padang lamun, ada yang dari larva hingga juvenile hidup di lamun kemudian dewasa ke perairan lepas. Beberapa spesies ikan keberadaannya di padang lamun hanya untuk mencari makan (seperti ikan beronang). Keberadaan Ichtyiofauna di padang lamun diduga berkaitan erat dengan fungsi padang lamun sebagai tempat asuhan larva dan juvenile berbagai jenis ikan yang memanfaatkannya (La rkum et al., 1989).

Adanya kerusakan padang lamun sebagai hasil dari dampak kegiatan manusia merupakan ancaman yang serius bagi kelestarian padang lamun dan organisme laut yang berasosiasi di dalamnya. Ancaman alami lainnya yang dapat mengurangi kelestarian ekosistem padang lamun antara lain adalah gelombang laut, angin topan, tsunami, aktivitas vulkanik, kompetisi antar spesies dan pemangsaan, perubahan iklim dan penyakit (Fortes, 1990). Ancaman utama yang mempengaruhi keberadaan ekosistem padang lamun di perairan Jepara adalah sedimentasi, kegiatan pariwisata bahari, pencemaran limbah domestik dan kegiatan menangkap ikan. Beberapa masyarakat biasa memanfaatkan padang lamun sebagai tempat pemancingan ikan laut. Ancaman terhadap ekosistem padang lamun tersebut dapat mempengaruhi keberadaan populasi organisme laut yang hidup didalamnya, temasuk dapat mempengaruhi struktur komunitas larva ikan yang banyak memafatkan padang lamun sebagai daerah asuhan (Tomascik et al., 1997).

Penelitian yang pemah dilakukan oleh Adi (2007) menunjukkan bahwa kerapatan lamun di suatu ekosistem di wilayah pesisir dapat mempengaruhi kelimpahan larva ikan. Semakin rapat tegakan lamun di suatu perairan maka kelimpahan larva ikan akan semakin tinggi. 
Karakteristik habitat padang lamun sangat berpengaruh pada kelimpahan dan distribusi larva dan organism laut lainnya yang berasosiasi di dalamnya. Hal ini dikarenakan adanya pengaruh kondisi fisika, kimia dan biologi perairan yang sangat mempengaruhi kondisi padang lamun. Parameter-parameter tersebut antara la in adalah: suhu, kecepatan arus, kecerahan, salinitas, fraksi substrat dasar, keberadaan fitoplankton dan zooplankton serta hewan bentik lainnya. Selain itu kerapatan jenis lamun sangat tergantung dari fraksi substrat serta kondisi kimia zat hara substrat dasar tempat lamun tumbuh (Tomascik et al., 1997). Hasil penelitian yang telah dilakukan oleh Riniatsih et al. (2001) menunjukkan bahwa substrat dasar yang didominasi oleh lumpur berpasir dengan kandungan hara yang tinggi di perairan sekitar mangrove lebih banyak disukai oleh lamun spesies Enhalus acoroides dan daerah dengan substrat pasir berlumpur lebih disukai lamun spesies Thalassia hemprichii (lokasi Mororejo dan Teluk Awur). Sedangkan habitat dengan substrat pasir halus lebih banyak disukai oleh lamun spesies Halodule uninervis, $\mathrm{H}$. pinifolia dan Syringodium isoetifoium di Lokasi Bandengan (Riniatsih et al., 2007).

\section{MATERI DAN METODE}

Materi yang digunakan dalam penelitian ini adalah sampel pasca larva ikan yang tertangkap pada beberapa lokasi selama penelitian di padang lamun perairan Jepara. Pada penelitian ini yang diamati adalah kelimpahan jenis larva ikan pada kumunitas lamun. Sela in materi utama tersebut di atas, \% Penutupan lamun dan beberapa parameter hidrofisik perairan juga diukur, antara la in suhu, salinitas, kecerahan, kecepatan arus, oksigen terlarut, kandungan bahan orga nik da n nutrien di pera iran.

Metoda yang digunakan dalam penelitian ini adalah studi kasus dan cara pengumpulan data dengan menggunakan sample survey method, yaitu metoda pengumpulan data dengan cara pengamatan terhadap sebagian populasi yang hasilnya diharapkan dapat menggambarkan sifat populasi dari obyek penelitian, sehingga dapat digunakan untuk menggambarkan suatu pupolasi di suatu habitat pada waktu tertentu (Mulyani, 1988)

Lokasi penelitian ditentukan secara Purposif, yaitu penentuan titik sampling dengan terlebih dahulu melalui beberapa pertimbangan. Penentuan lokasi didasarkan pada distribusi jenis lamun. Lokasi penelitian meliputi perairan padang lamun di Teluk Awur, Bandengan, dan perairan Mororejo Jepara. Masing-masing stasiun dibagi menjadi tiga sub stasiun (Teluk Awur. T1, T2 dan T3 ; Bandengan: B1., B2 dan B3 ; Mororejo; M1, M2 dan M3) dengan 4 kali pengambilan sampel.

Pengambilan sampel larva ikan dilakukan dengan menggunakan alat tangkap jaring sudu (Push Net) di masingmasing stasiun penelitian. Jaring sudu dengan mesh size mata jaming $1 \mathrm{~mm}$ berbentuk segitiga dengan alas selebar 3 meter, tinggi 2 meter dan panjang kantong 4 meter. Pengoperasian alat dengan cara didorong di dasar perairan sepanjang 150 meter sejajar garis pantai. Pengambilan sampel dilakukan 4 kali dengan interval sampling setiap 2 minggu sekali. Hasil tangkapan berupa larva ikan dimasukkan ke dalam botol sampel yang telah diisi formalin $4 \%$ dengan volume 100 $\mathrm{ml}$. Selanjutnya sampel dibawa ke Laboratorium Biologi Junusan IImu Kelautan FPIK Undip untuk dilakukan sortir dan identifika si.

Selama pengambilan sampel juga dilakukan pengukuran parameter hidrooseanografi (suhu, salinitas, kecepatan arus, kecerahan, kandungan bahan organik, oksigen terlarut dan nutrien perairan) dan data pendukung lainnya (meliputi \% Penutupan lamun).

Data yang digunakan untuk a nalisa data adalah meliputi Komposisi Relatif jenis dan Kelimpahan larva ikan. Struktur Kumonitas larva ikan dihitung dengan melihat indeks Keanekaragaman, Indeks Keseragaman dan Dominasi Jenis. 


\section{HASILDAN PEMBAHASAN}

Jumlah total larva ikan yang tertangkap selama penelitian adalah sebanyak 570 ekor dari 12 famili. Hasil identifikasi memperlihatkan famili ikan yang tertangkap adalah Apogonidae, Carapidae, Blenniidae, Egraulidae, Epilephenidae, Geridae, Heniranphidae, Labridae, Gobiidae, Lutjanidae, Syngnathidae, Mullidae, dan Siganidae. Famili ikan yang teridentifikasi didominasi dari famili Gobiidae, Bleniidae dan Eugraulidae. Berdasarkan lokasi pengamatan, lokasi perairan Bandengan merupakan lokasi dengan hasil tangkapan larva ikan tertinggi, yaitu seba nyak 9 fa mili, perairan Teluk Awur sebanyak 7 famili dan perairan Mororejo sebanyak 5 famili (Tabel $1)$.

Kelimpahan larva ikan di lokasi perairan padang lamun di Bandengan memiliki kelimpahan larva ikan yang tertinggi apabila dibandingkan dengan kelimpahan larva ikan yang diperoleh di lokasi pengamatan yang lainnya, yaitu sebesar 266 individu/1000m 3 (pada pengambilan sampel ke-3) dari 9 famili. Sedangkan nilai kelimpahan larva ikan dilokasi Teluk Awur sebanyak 189 ind $/ 1000 \mathrm{~m}^{3}$ (pada pengambilan sampel ke-2) dan di Lokasi Mororejo sebanyak 121 ind/1000meter ${ }^{3}$ (pada pengambilan sampel ke-3). Kelimpahan individu dan familia larva ikan dapat dilihat pada Gambar 1.

Nilai \% Penutupan selama penelitian di masing-masing lokasi pengamatan menunjukkan kisaran antara 2,79-12,90\% untuk lamun jenis Enhalus acoroides, 3,33$29,77 \%$ untuk lamun jenis Thalassia hemprichii, $\quad 0-21,55 \%$ untuk lamun jenis Cymodocea semulata, 0-10.49\% untuk Syring odium isoetifolium , 0-7,45 \% untuk Halophila ovalis dan 0-41,29\% untuk Halodule uninervis di semua lokasi pengamatan. (Tabel2).

Hasil Perhitungan \% Penutupan lamun menunjukkan perairan Bandengan mempunyai \% Penutupan yang tertinggi dibandingkan \% Penutupan lamun pada lokasi penelitian yang lainnya. Hasil perhitungan untuk struktur komunitas larva ikan yang tertangkap selama penelitian menunjukkan hasil yang hampir sama untuk setiap sta siunnya (Tabel 3).

Jenis-jenis ikan laut banyak yang bukan spesies asli disuatu ekosistem tempat jenis tersebut ditemukan. Beberapa jenis ikan memanfaatkan padang lamun sebagai tempat untuk memijah atau mencari makan di susatu ekosistem yang mempunyai produktivitas tinggi (Chute dan Tumer, 2001).

Tabel 1. Tingkat Keha diran Larva Ikan yang Tertangkapdi Lokasi Penelitian

\begin{tabular}{lccc}
\hline \multirow{2}{*}{ Famili lkan } & \multicolumn{3}{c}{ Stasiun } \\
\cline { 2 - 4 } & Teluk Awur & Bandengan & Mororejo \\
\hline Apogonidae & + & + & - \\
Carapidae & - & - & + \\
Blenniidae & + & + & + \\
Egraulidae & + & + & - \\
Epilephenidae & - & - & + \\
Geridae & - & - & + \\
Heniranphidae & - & + & - \\
Labridae & - & + & - \\
Gobiidae & + & + & - \\
Lutjanidae & + & + & - \\
Syngnathidae & + & + & + \\
Mullidae & - & - & - \\
Siganidae & + & + & - \\
\hline
\end{tabular}


Tabel 2. Rata-rata \% Penutupan Lamun di Lokasi Penelitian

\begin{tabular}{ccccccc}
\hline Sub & \multicolumn{7}{c}{ Penutupan Spesies lamun (\%) } \\
\cline { 2 - 7 } Stasiun & Ea & Th & C s & Si & Ho & Hu \\
\hline T1 & 2,79 & 3,34 & 0 & 0 & 0 & 0 \\
T2 & 5.03 & 29,77 & 1,62 & 4,53 & 0 & 0 \\
T3 & 5,83 & 24,78 & 1,50 & 5,47 & 0 & 0 \\
B1 & 12,90 & 10,45 & 6,20 & 10,34 & 3,29 & 21,67 \\
B2 & 11,92 & 29,14 & 21,55 & 10,49 & 7,45 & 41,29 \\
B3 & 8,42 & 33,33 & 17,59 & 15,53 & 3,21 & 34,42 \\
M1 & 4,59 & 20,54 & 1,89 & 0 & 0 & 0 \\
M2 & 3,17 & 20,83 & 0 & 0 & 0 & 0 \\
M3 & 3,74 & 5,47 & 0 & 0 & 0 & 0 \\
\hline
\end{tabular}

Keterangan: $\mathrm{Ea}=$ Enhalus ac oroides; $T$ h $=$ Tha la siia hempric hii ; Cs =Cymodocea semulata; $\mathrm{Si}=$ Syringodium isoetifolium; $\mathrm{Ho}=$ Halophila ovalis; $\mathrm{Hu}=\mathrm{Ha}$ lodule uninervis

Tabel 3. Hasil Perhitungan Indek Keanekaragaman ( $\left.H^{\prime}\right)$, Indeks Keseragaman (E) dan Indeks Dominasi (c) untuk jenis Larva Ikan selama penelitian

\begin{tabular}{cccc}
\hline Sub Stasiun & $\mathrm{H}^{\prime}$ & $\mathrm{E}$ & $\mathrm{C}$ \\
\hline T1 & 1,1958 & 0,5556 & 0,1443 \\
T2 & 2,1357 & 0,6774 & 0,1332 \\
T3 & 1,7823 & 0,5409 & 0,1844 \\
B1 & 1,9887 & 0,5667 & 0,1776 \\
B2 & 2,1378 & 0,6850 & 0,1321 \\
B3 & 2,1777 & 0,5578 & 0,1300 \\
M1 & 1,5780 & 0,5877 & 0,3432 \\
M2 & 0,7886 & 0,5449 & 0,1494 \\
M3 & 0,6778 & 0,3569 & 0,2065 \\
\hline
\end{tabular}

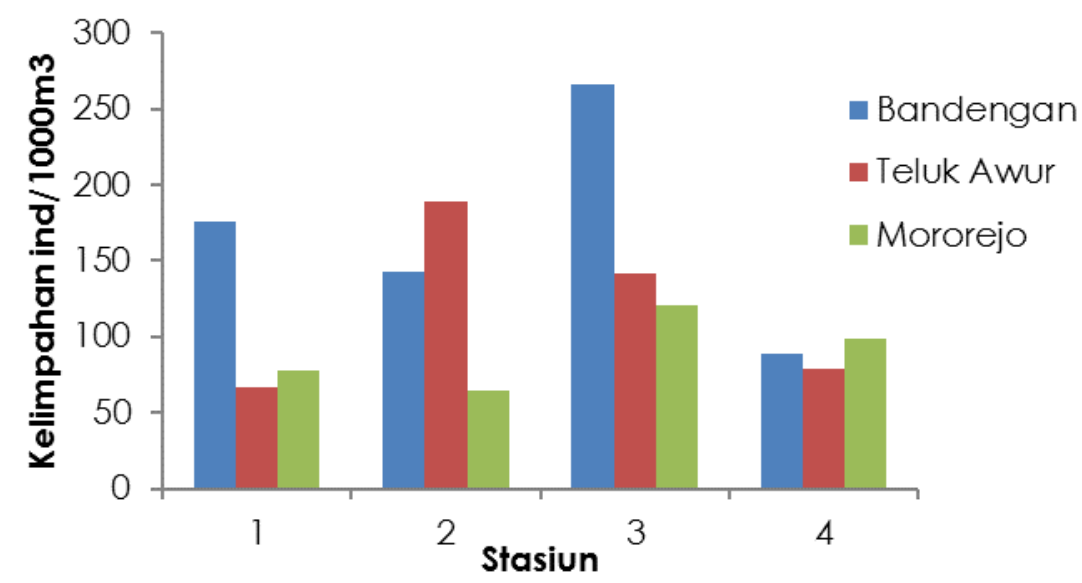

Gambar 1. Kelimpahan Larva Ikan di Ekosistem Pa dang Lamun Perairan J epara

Ikan yang mempunyai habitat asli di daerah terumbu karang tidak sepenuhnya hidup di daerah karang. Beberapa famili ikan yang diperoleh selama penelitian menunjukkan jenis-jenis ikan yang bukan penghuni padang lamun asli, melainkan jenis-jenis ikan yang bemigrasi di padang lamun untuk memanfaatkan padang lamun sebagai daerah pemijahan. Famili Carangidae, Siganidae, dan Lutjanidae merupakan jenis-jenis ikan yang berasosiasi dengan padang lamun sebagai tempat untuk mencari makan. (Dahuri, 2003). Banyak dari jenis-jenis ikan laut yang melakukan pemijahan di perairan yang tidak jauh dari 
pantai, sehingga telur atau larvanya bermigrasi atau terbawa arus menuju tempat pembesaran dan menggunakan sinyal-sinyal lingkungan tertentu seperti adanya arus laut, unsur hara, kandungan mineral kimia perairan tertentu ataupun struktur habitat yang spesifik di ekosistem padang lamun, mangrove atau muara sungai (Huijbers et al., 2008).

Larva ikan yang telah menetas akan menetap di suatu habitat hinggamelewati vase larva pada siklus hidupnya untuk mencapai juvenile. Setelah melewati masa juvenile ikan akan bemigrasi kembali untuk mendapatkan habitat yang cocok untuk tinggal hingga mencapai fase dewasa (Moriniere et al., 2001).

Famili ikan yang diperoleh selama penelitian didominasi oleh famili Gobiidae, Blennidae dan Eugraulidae. Diduga melimpahnya larva ikan dari famili Gobiidae dikarenakan bertepatannya waktu pengambilan sampel pada bulan Mei-September menupakan waktu pemijahan ikan famili Gobidae. Sela in itu famili Gobbidae, famili Labridae dan famili Pomacentridae merupakan femili penyusun utama yang banyak ditemukan di perairan pesisir (Allen dan Adrin, 2003). Larva ikan famili lainnya yang banyak ditemukan adalah larva ikan yang berasal dari famili Egraulidae yang secara umum termasuk dalam famili ikan yang hidup di perairan dangkal, padang lamun dan estuaria (Food and Agriculture Organization, 2001). Famili Egraulidae biasa menyebar disepanjang perairan Indo-Pasifik. Sedangkan jenis ikan Blenniidae merupakan famili ikan yang biasa ditemukan di tenumbu karang. Karena penelitian ini pada beberapa lokasi dilakukan di habitat yang berdekatan dengan terumbu karang, maka diduga ada keterkaitan antara padang lamun dan terumbu karang dalam hal migrasi ikan (Smith-Vaniz dan Rose, 2012).

Lana ikan yang tertangkap selama penelitian ini, lebih banyak ditemukan di lokasi Bandengan, karena diduga kondisi lingkungan perairan Bandengan dengan \% Penutupan lamun yang relative tinggi dibandingkan dengan lokasi la in merupakan habitat yang cocok sebagai tempat untuk berlindung dan mencari makan. Perairan Teluk Awur merupakan lokasi pengamatan yang menempati unutan kedua dari jumlah famili larva ikan yang tertangkap. Hal ini diduga karena jenis dan \% Penutupan lamun yang ditemukan di perairan Teluk Awur relative tinggi juga, sedangkan lokasi Mororejo merupakan lokasi yang paling sedikit ditemukan banyaknya famili larva ikan. Kondisi perairan Mororejo yang relative terbuka dengan substrat pasir hitam berlumpur dengan sedimentasi yang relative tinggi dan keruh sehingga paling sedikit ditumbuhi lamun. Hal ini diduga yang menyebabjkan famili ikan yang ditemukan relative lebih sedikit apabila dibandingkan dengan lokasi pengamatan yang lainnya.

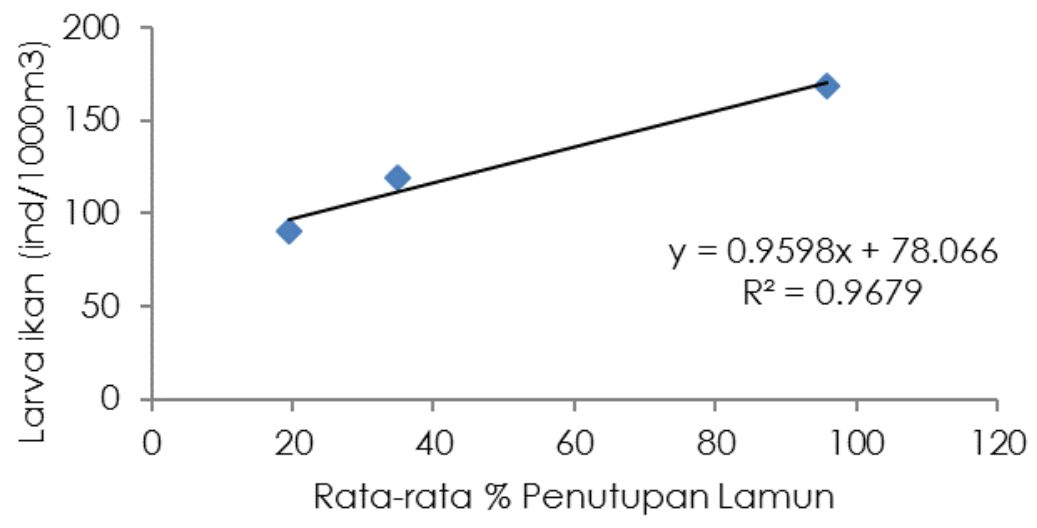

Gambar 2. Korelasi Regresi antara \% Penutupan Lamun dan Kelimpahan Larva lkan di Lokasi penelitian 
Nilai indeks Keanekaragaman $\left(\mathrm{H}^{\prime}\right)$ hasil perhitungan menunjukkan nilai tertinggi pada daerah Bandengan $(2,177)$ dan terendah pada lokasi perairan Mororejo $(0,678)$. Kisaran indeks keanekaragaman ini dapat menunjukkan bahwa nilai keanekaragaman larva ikan yang tertangkap selama penelitian menunjukkan pada kisaran rendah hingga sedang. Nilai indeks Keanekaragaman yang berda pada setiap lokasi penelitian menunjukkan bahwa banyak faktor yang berpengaruh pada jumlah populasi ikan, hal ini diduga karena adanya perbedaan \% Penutupan lamun, atau faktor-faktor hidro-oseanografi yang berbeda di setiap lokasi penelitian (Olli, 2003).

Nilai indeks Keseragaman yang terhitung dari hasil jumlah larva ikan yang tertangkap menunjukkan kisaran antara 0,3569-0,6850 deangan nilai tertinggi di lokasi Bandengan dan terendah di Mororejo. Semakin kecil nilai indeks keseragaman $(E \leq 0,4)$ berarti tingkat keseragaman jumlah tiap famili ikan tidak sama pada suatu lokasi, dengan demikian ada kecenderungan satu famili larva ikan yang mendominasi. Sebaliknya jika nilai indeks keseragaman mendekti $(E \geq 0,6)$ menunjukkan keseragaman jumlah individu masing-masing famili larva ikan pada suatu lokasi pengamatan sama ata u merata. Kisaran $(E \leq 0,4)$ ditunjukkan pada lokasi Mororejo, sedangkan nilai yang mendekati $(E \geq 0,6)$ diperoleh pada lokasi pengamatan di perairan Bandengan.

Nilai indeks Dominasi (C) terlihat berkisar antara 0,1321-0,3432 yang terhitung sebagai hasil jumlah famili ikan yang tertangkap selama penelitian. Indeks dominasi terendah diperoleh dari perairan Teluk Awur dan tertinggi dari perairan Mororejo. Secara umum dari hasil perhitungan indeks Dominasi menjukkan bahwa tidak ada famili larva ikan yang mendominasi di suatu lokasi yang berbeda secara signifikan.

Kerapatan lamun merupakan salah satu faktor yang dapat mempengaruhi kelimpahan larva ikan di ekosistem padang lamun. Tajuk daun lamun yang rapat dapat menenangkan arus di padang lamun serta dapat menciptakan kondisi yang sejuk dari sinar matahari, sehingga dapat dipergunakan oleh larva ikan sebagai tempat untuk berlindung dari predator. Hasil analisa korelasi regresi menunjukkan bahwa semakin besar \% Penutupan lamun, semakin banyak juga larva ikan yang tertangkap di lokasi tersebut $\left(R^{2}=0,967\right)$.

Keterkaitan ekosistem padang lamun denagn ekosistem wilayah pesisir la innya, seperti adanya vegetasi nagrove dan terumbu karang, merupakan salah satu faktor yang turut menentukan kekayaan jenis ata u famili larva ikan yang tertangkap di suatu lokasi. Daerah padang lamun yang berdekatan dengan ekosistem mangrove dan terumbu karang biasanya lebih banyak mempunyai biodiversitas yang tinggi dengan adanya migrasi biota dari ke tiga ekosistem tersebut, apabila dibandingkan dengan daerah yang tidak berdekatan dengan ekosistem terumbu karang dan mangrove ((Nagelkerken et al., 2000). Hal ini terlihat pada lokasi pengamatan di perairan Bandengan dan Teluk Awur yang berdekatan dengan perairan yang terdapat vegetasi mangrove dan terumbu karang. Dari hasil jumlah famili ikan yang tertangkap di lokasi Bandengan dan Teluk Awur relative lebih tinggi apabila dibandingkan dengan lokasi pengamatan di perairan Mororejo

\section{KESIMPULAN}

Hasil pengamatan dan perhitungan jumlah famili ikan yang diperoleh selama penelitian menunjukkan adanya keterkaitan antara perbedaan \% Penutupan lamun dan petbedaan kondisi lingkungan khususnya pengaruh keberadaan ekosistem mangrove dan terumbu karang terhadap jumlah famili larva ikan yang tertangkap.

\section{DAFTAR PUSTAKA}

Adi, W. 2007. Komposisi dan Kelimpahan Larva dan Juvenil Ikan yang Berasosiasi dengan Tingkat Kerapatan 
lamun yang Berbeda di Pulau Panjang Jepara. Jumal Sumberdaya Perairan. ISSN 1978-1652. Vol 1. Edisi 1.

Adrim, M. 2006. Assosiasi Ikan di Pdang lamun. Pusat Penelitian Oseanografi UPI. J a karta. Oseana. 31 (4):1-7.

Allen, G.R. \& M. Adrin. 2003. Coral Reef Fishes of Indonesia. Zoological Studies. 42(1):1-72

Chute, A.S. \& J .T. Tumer. 2001. Plankton Studies in Buzzards Bay Massa chusetts, USA. V. Ic htyoplankton. 1987 to 1993. Mar. Ecol. Prog. Ser, 224: 45-54.

Dahuri, R. 2003. Keanekaragaman Hayati Laut. Penerbit PT. Gramedia Pustaka Uta ma, J a karta XXXIII + $412 \mathrm{hlm}$.

Danovaro, R.C., C. Gambi \& S. mirto. 2002. Meiofaunal Production and energy Transfer Efficienvcy in a Seagrass Posidonia oceanica Bed in the Wsetem Mediteranian. mar Ecol. Prog. ser. 234:95-104

Food and agricuktural Organization (FAO) 2001. Species Identification Guide for Fishery Purposes: The Living Marine Resourches of the Westwem Central Pacific. Vol. 3-6 (Editors: K.E. Carpenter \& F.A. Niem) Food and Acgricuktural Organizatiob of The United nation, rome.

Fortes, M.D. 1990. Seagrasses: A Resources Unknown in The Asean Region. Iclam Education Series 5. Intemational Center for Living Aquatic. Resources Management Manila, Philippines.

Helfman, G.S., B.B. Collete, D.E. Facey dan B.W. Bowen 2009. Diversity of Fishes: Biology, Evoluation and Ecology. 2nd. Eds. Wiley-Blacwell: John Wiley and Sons Ltd. Chic hester. UK.737 pp.

Huijbers, C.M. E.M. Mollee \& I. Negelkerken. 2008. Post-Larval Grunts (Haemulon flavolineatum) Distinguish Between Seagrass, Mangrove and Cotral Reef Water. Implication for Recognition of Potential Nursery Habitats . Joumal of Experimental Marine Biology ang Ecology. 357:134139.

Moriniere, E,C., B.J.A. Phollux, I. Nagelkerken, \& G.V. Velde. 2000. PostSettelment Life Cycle Migration
Pattems and Habitat Preference of Coral Reef Fish that Use Seagrass and Mangrove Habitat as Nurseries. Estuarine Coastal and Shelf Science (2002) 55, 309-321. Netherlans.

Nagelkerjken, I., M. Dorenbosch, W.C.E.P. Verberk, E. Coeheret de la Muriniere \& G. Van der Velde. 2000. Importance of Shallow-Water Biotope of the Caribean Bay for J uvenile Coral Reef Fish: Pattems in Biotope Association, Community Structure and Spatial Distribution. Mar. Ecol. Prog. Ser.. 2002:175-192.

Olli, A.H. 2003. kajian Faktor Fisik yang Mempengaruhi Distribusi Ichtyoplankton (Awal Dur Hidup Ikan). Pengantar Falsa fah Sa ins (PPS702)

Riniatsih, I., Imza Herma wan dan Sri Sedjati. 2000. Komunitas Pasca larva Udang Fa mili Penaeideae dan Hubungannya dengan Karakteristik Habitat di Padang Lamun Perairan Jepara. Jumal Ilmu Kelautan. Vol 5 (19) September 2000.

Riniatsih, I., Widianingsih dan S. Sedjati. 2001. Kandungan Nutrisi Substrat Dasar dan Hubungannya dengan Distribusi Spesies Lamun di Perairan Jepara. Hasil Penelitian (Tidak dipublikasikan) Lemlit Universitas Diponegoro. Semarang.

Riniatsih, l., dan Widianingsih. 2007. Kelimpahan dan Pola sebaran Kerang-kerangan (Bivalvia) di Ekosistem Padang Lamun Perairan Jepara. Jumal Ilmu Kelautan. Vol 12 (1) Ma ret 2007.

Romimuhtarto, K dan S. Juwana. 2004. Meroplankton Laut; Larva Hewan laut yang Menjadi Plankton. Djambatan. Jakarta

Smith-Vaniz, W.F. \& J.M. Rose. 2012. Adelptremus Leptus, a New Genus and Species of Sabertooth Blenny from the Red Sea (Teleostei: Blennidae: Nema phini). Zootaxa. 3249: 39-46.

Tomascick, T., A.J. Mah, A. Nontji \& M.K. Kasim Moosa. 1997. The Ec ology of the Indonesia Seas. Part One. Periplus Edition (HK) Ltd., Singapore. 